\title{
Ultrasound Assisted Esterification of Rubber Seed Oil for Biodiesel Production
}

\author{
Widayata*, Berkah Fajar Tamtomo Kiono ${ }^{\mathrm{b}}$ \\ a Center of Biomass and Renewable Energy, Chemical Engineering Department, Faculty of Engineering, Diponegoro University, \\ Jl.Prof Sudharto,SH-Tembalang, Semarang INDONESIA \\ b Mechanical Engineering Department, Faculty of Engineering, Diponegoro University, \\ Jl.Prof Sudharto,SH-Tembalang, Semarang INDONESIA
}

\section{Article history:}

Received December 21, 2011 Received in revised form Jan 8, 2012 Accepted January 17, 2012 Available online

\begin{abstract}
Production of biodiesel is currently shifting from the first to the second generation in which the raw materials are mostly from non-edible type oils and fats. Biodiesel production is commonly conducted under batch operation using mechanical agitation to accelerate mass transfers. The main drawback of oil esterification is the high content of free fatty acids (FFA) which may reduce the yield of biodiesel and prolong the production time (2-5 hours). Ultrasonification has been used in many applications such as component extraction due to its ability to produce cavitation under certain frequency. This research is aimed to facilitate ultrasound system for improving biodiesel production process particularly rubber seed oil. An ultrasound unit was used under constant temperature $\left(40^{\circ} \mathrm{C}\right)$ and frequency of $40 \mathrm{~Hz}$. The result showed that ultrasound can reduces the processing time and increases the biodiesel yield significantly. A model to describe correlation of yield and its independent variables is yield $(\mathrm{Y})=43,4894-0,6926 \mathrm{X}_{1}+1,1807 \mathrm{X}_{2}-$ $7,1042 X_{3}+2,6451 X_{1} X_{2}-1,6557 X_{1} X_{3}+5,7586 X_{2} X_{3}-10,5145 X_{1} X_{2} X_{3}$, where $X_{1}$ is mesh sizes, $X_{2}$ ratio oil: methanol and $X_{3}$ type of catalyst.
\end{abstract}

Keywords: Rubber seed oil, Ultrasound, Esterification, Biodiesel, Yield

\section{Introduction}

Nowadays, demands of fossil energy in Indonesia are significantly increasing while oil reserves will be diminishing within 20 years [1]. As a consequence, there are serious attempts in finding new alternative energy i.e. hydrogen cells, solar energy and wind power. However, the above technologies are still at the development stage, and still not feasible to be applied from economic point of view [2].

The feasible option is developing the technology for biodiesel production as it is biodegradable and nontoxic product. Biodiesel also has low undesirable emission, and environmental friendly. Biodiesel can be produce from vegetable oils which is generated from renewable resources. They practically have less sulphur content, offer no storage difficulty, and they have excellent lubrication properties. Moreover, converting vegetable oils to become biodiesel indirectly can improve the absorption of carbon dioxide compare to the direct burning (conventional method in generating energy) $[3,4]$.

Rubber seed oil is one of vegetable oil which has high unsaturated fatty acids (80\%) and thus makes this oil potential source for biodiesel raw material. High unsaturated fatty acid leads to high value cloud point and cetane number as the important properties of biodiesel [5].

The composition of fatty acid and other properties of rubber seed oil are shown in Table 1 . Rubber seed oil consists of $18.9 \%$ saturation comprising of palmitic and stearic acids and $80.5 \%$ unsaturation comprising mainly of oleic, linoleic and linolenic acids. The presence of the saturation fatty acid methyl

\footnotetext{
* Corresponding author: Tel: +62-24-7460058

E-mail:dayat.widayat@yahoo.com
} 
Citation: Widayat, Kiono BFT (2012) Ultrasound Assisted Esterification of Rubber Seed Oil for Biodiesel Production. Int. Journal of Renewable Energy Development 1: 1-5

Table 1

Rubber seed oil characteristic [5]

\begin{tabular}{|c|c|c|c|c|}
\hline Property & Rubber seed oil & Sunflower oil & Rapeseed Oil & Soybean oil \\
\hline \multicolumn{5}{|l|}{ Fatty acid composition } \\
\hline Palmitic acid- C16:0 & 10.2 & 6.8 & 3.49 & 11.75 \\
\hline Stearic acid-C18:0 & 8.7 & 3.26 & 0.85 & 3.15 \\
\hline Oleic acid-C18:1 & 24.6 & 16.93 & 64.4 & 23.26 \\
\hline Linoleic acid,C18:2 & 39.6 & 73.73 & 22.3 & 55.53 \\
\hline Linolenic acid-C18:3 & 16.3 & 0 & 8.23 & 6.31 \\
\hline Specific gravity & 0.91 & 0.918 & 0.914 & 0.92 \\
\hline Viscosity $(\mathrm{mm} / \mathrm{s})$ at $40^{\circ} \mathrm{C}$ & 66.2 & 58 & 39.5 & 65 \\
\hline Flash point $\left({ }^{\circ} \mathrm{C}\right)$ & 198 & 220 & 280 & 230 \\
\hline Caloric value (MJ/kg) & 37.5 & 39.5 & 37.6 & 39.6 \\
\hline Acid value & 34 & 0.15 & 1.14 & 0.2 \\
\hline
\end{tabular}

esters will increase the cloud point, cetane number and also will improve stability. In other hand, the excess of poly unsaturated may reduce the cloud point and cetane number and stability.

Trans-esterification (alcoholises) is the chemical reaction between triglycerides and alcohol in the presence of catalyst to produce methyl-ester and glycerine [4]. The overall trans-esterification reaction can be shown by the following reaction:

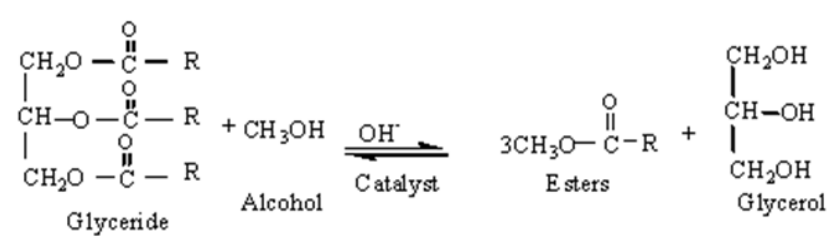

The glycerides are converted into glycerol and yielding one methyl ester molecule (FAME) which has properties comparable to biodiesel.

Production of biodiesel from vegetable oils i.e. soy, jatropha, sunflower seed or microalgae, using conventional process is relatively slow (almost 4-5 hours), it needs more catalyst and alcohol while the esterification reaction is not fully completed. Moreover, the high formation of by-product gives low yield of biodiesel and during the conversion process not all fatty acid chains are turned into biodiesel which consequently reduces the quality and the yield. The current conventional process only can achieve maximum yield of $85 \%$ during esterification reaction.

Normally, by stoichiometry, three moles of alcohol are needed for each mole of triglyceride, but in reality a higher molar ratio is used in order to get higher yield of ester product. Even though esters are the main products of the trans-esterification reactions, glycerine as the byproduct is getting much attention due to its role in decreasing the conversion. Alcohol used in the reaction is normally methanol or ethanol however the yield of esterification is independent of the type of alcohol. The common alcohol used is methanol due its economical reason. Sulfic acid $\left(\mathrm{H}_{2} \mathrm{SO}_{4}\right)$ is normally used for acid catalyst while potassium hydroxide $(\mathrm{KOH})$ and sodium hydroxide $(\mathrm{NaOH})$ are the commonly used for alkaline catalysts. Alkaline catalysed trans-esterification of vegetable oils is possible only if the acid value of oil is less than 4. Higher percentage of FFA in the oil will reduce the yield of the esterification process.

The free fatty acid (FFA) content of rubber seed oil is about $17 \%$. The yield of esterification process decreases considerably if FFA value is greater than $2 \%$. Transesterification would not occur if FFA content in the oil were about $3 \%$. It has been found that the alkaline catalysed trans-esterification process is not suitable to produce esters from unrefined oils. Vegetable oils refining can increases the overall production cost of the biodiesel. Acid esterification is a typical method of producing biodiesel from high FFA oil [6]. But it requires high methanol and very time consuming.

Therefore, an alternative process is really required to reduce the processing time, to increase the yield, to lower amount un-reacted methanol and also catalyst, and to increase the mass transfer. Ultrasound $(\sim 20 \mathrm{kHz}$ to $10 \mathrm{MHz}$ ) is cyclic sound pressure with a frequency greater than the upper limit of human hearing [7]. The ultrasound technique has been used for several applications such as extraction of xyloglucan from apple pomace [8]; extraction total fat from oleaginous seeds $[9,10]$; extraction of anthraquinones from roots of Morinda citrifoli [11]; extraction of Ilex paraguariensis leaves [12]; and leaching process of Geniposide [13].

The advantages of using ultrasound in transesterification process is that ultrasound generate bubble cavitation which replacing the mechanical agitation by stirrer, and therefore it is required for enhancing the esterification reaction [14, 15]. This paper describes the potential use of ultrasound for assisting biodiesel production using rubber seed oil.

\section{Experimental Method}

\subsection{The procedure of experiment}

The rubber seed was obtained from Perkebunan Karet Ngobo, Ungaran, Indonesia. The rubber seed was extracted for oil generation using mechanical pressing. The rubber seed was then fined for sizes 1-1.16 mm. The purification and analysis were done at Laboratory of Analysis, Chemical Engineering Department. After extraction, the oil was separated from the solid waste 
and was esterified using methanol and catalyst. The ultrasound was facilitated to enhance the mixing instead of mechanical agitation. The biodiesel product was purified using distillation to separate from methanol and glycerol. The schematic diagram for biodiesel production was shown in Figure 2.

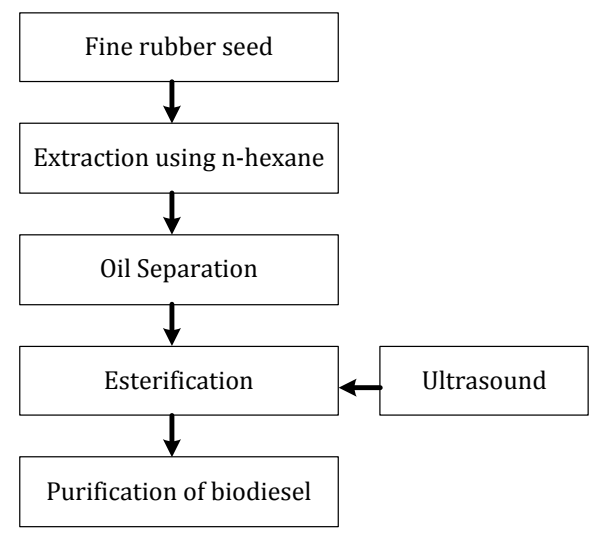

Fig 2. The procedure to make biodiesel using ultrasound

\subsection{Experimental design}

This research conducted using experimental factorial design with 2 levels as shown in Table 2 . The independent variable used in this research are temperature $\left(40^{\circ} \mathrm{C}\right)$, pressure $(1 \mathrm{~atm})$, frequency $(40$ $\mathrm{KHz}$ ), sample weight (50 gram), amount of catalyst (3\% weight), while the dependent variables are: mesh sizes (1 $\mathrm{mm}$ and 1,16 $\mathrm{mm}$ ), solvent : oil ratio (2:1 and $3: 1$ ), type of catalyst ( $\mathrm{NaOH} 1 \mathrm{~N}$ and $\mathrm{H}_{2} \mathrm{SO}_{4} 98 \%$ ).

Table 2

Factorial design for 3 variables

\begin{tabular}{cccc}
\hline \multirow{2}{*}{ Run } & \multicolumn{3}{c}{ Variables } \\
\cline { 2 - 4 } & $\mathrm{B}$ & $\mathrm{P}$ & $\mathrm{K}$ \\
\hline 1 & -1 & -1 & -1 \\
2 & +1 & -1 & -1 \\
3 & -1 & +1 & -1 \\
4 & +1 & +1 & -1 \\
5 & -1 & -1 & +1 \\
6 & +1 & -1 & +1 \\
7 & -1 & +1 & +1 \\
8 & +1 & +1 & +1 \\
9 & 0 & 0 & 0 \\
10 & 0 & 0 & 0 \\
\hline
\end{tabular}

Remarks:

(+): Upper limit; (-): Lower limit, and (0): Centre value; B : Mesh sizes: 1 - 1,16 $\mathrm{mm}$, with P: Ratio solvent: oil between $2: 1$ and $3: 1(\mathrm{w} / \mathrm{w})$ with K: Type of catalyst: acid (-) and base (+)

To calculate yield of the extractive -reactive process, fatty acid methyl ester (FAME) was determined by using Gas Chromatography (GC). The yield was calculated from the weight of FAME in the product divided by oil content in the rubber seed oil. To determine effect of each variable, their interaction and significant effect of each variable, the factorial design of 2 levels was used [16].
The equipment used in this experiment is shown in figure 3. This equipment was used for extractive reactive completed by ultrasound unit and distillation.
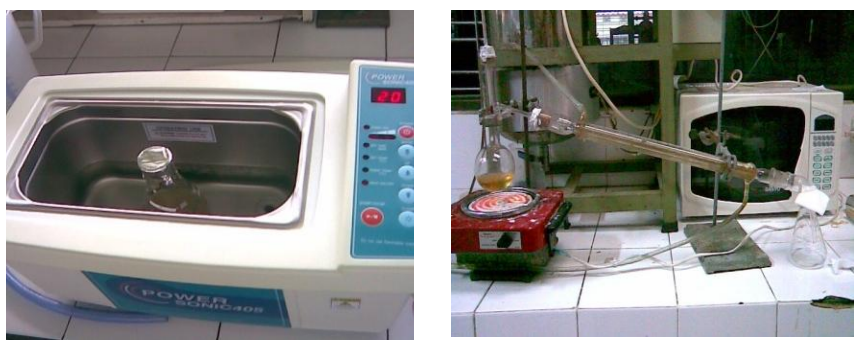

Fig 3. Ultrasound unit for esterification and distillation unit

\section{Results and Discussion}

\subsection{Reactive-extractive process}

At the stage of reactive-reactive process, triglycerides from rubber seed oil are converted to biodiesel and glycerol. The yield obtained from this process shows a promising result of applying ultrasound for esterification of rubber seed oil. The ultrasound can enhance the yield of biodiesel due to its cavitation for mixing and generating primary spot in the reactant (Table 3).

Tabel 3

Yield of esterification process

\begin{tabular}{|c|c|c|c|c|c|}
\hline Run & B & $\mathbf{P}$ & $\mathbf{K}$ & $\begin{array}{l}\text { Biodiesel } \\
\text { (gr) }\end{array}$ & Yield (\%) \\
\hline 1. & -1 & -1 & - & 11,77 & 62,11082 \\
\hline 2. & +1 & -1 & - & 9,14 & 48,23219 \\
\hline 3. & -1 & +1 & - & 7,04 & 37,1504 \\
\hline 4. & +1 & +1 & - & 10,40 & 54,88127 \\
\hline 5. & -1 & -1 & + & 5,53 & 29,18206 \\
\hline 6. & +1 & -1 & + & 5,63 & 29,70976 \\
\hline 7. & -1 & +1 & + & 9,15 & 48,28496 \\
\hline 8. & +1 & +1 & + & 7,27 & 38,36412 \\
\hline 9. & 0 & 0 & 0 & 6,29 & 33,19261 \\
\hline 10. & 0 & 0 & 0 & 2,82 & 14,88127 \\
\hline
\end{tabular}

The ultrasound wave has a huge energy at the surface tension which is reciprocal to the bubble radius. This short radius can generate energy which force the process occurred at lower temperature, compared to conventional operation $\left(60^{\circ} \mathrm{C}\right)$. Table 3 also shows that extraction and esterification could be done simultaneously

In determining the significant variables in the production process of biodiesel, the factorial design method was used. The linear correlation from response surface methodology delivers following equation:

Yield $=43,4894-0,6926 X_{1}+1,1807 X_{2}-7,1042 X_{3}$ $+2,6451 X_{1} X_{2}-1,6557 X_{1} X_{3}+5,7586 X_{2} X_{3}-10,5145$ $\mathbf{X}_{1} \mathbf{X}_{2} \mathbf{X}_{3}$ 
To determine significant and effect of interaction among variables, statistical analysis is required. Table 4 shows statistical analysis by using ANOVA method. The $p$ value of each variable is greater than $p$ in the table ( $p>0.05)$. Therefore, we assumed that all variables are significant and are not rejected as the model parameter.

The equation shows that coefficient of $X_{1}$ has a negative value, meaning that high yield can be obtained by decreasing mesh sizes because surface area of mass transfer of oil from rubber seed to solvent is larger and therefore accelerate the mass transfer. In other hand, coefficient of $\mathrm{X}_{2}$ is positive, meaning that the yield can be increased by using larger ratio of solvent. This is supported by [17] stating that molar ratio of substrate and methanol is one of important factors for transesterification process. In this experiment, molar ratio of methanol and rubber seed oil is $1: 2$ and 1:3. The highest significant parameter is coefficient of $\mathrm{X}_{3}$ namely type of catalyst.

This equation shows that coefficient in front of $\mathrm{X}_{1} \mathrm{X}_{2} \mathrm{X}_{3}$ has larger value (10.5145) and therefore the interaction among these variables is the most significant followed by coefficient of $X_{3}$ (7.1042). Therefore this variable is the second significant variable in the process.

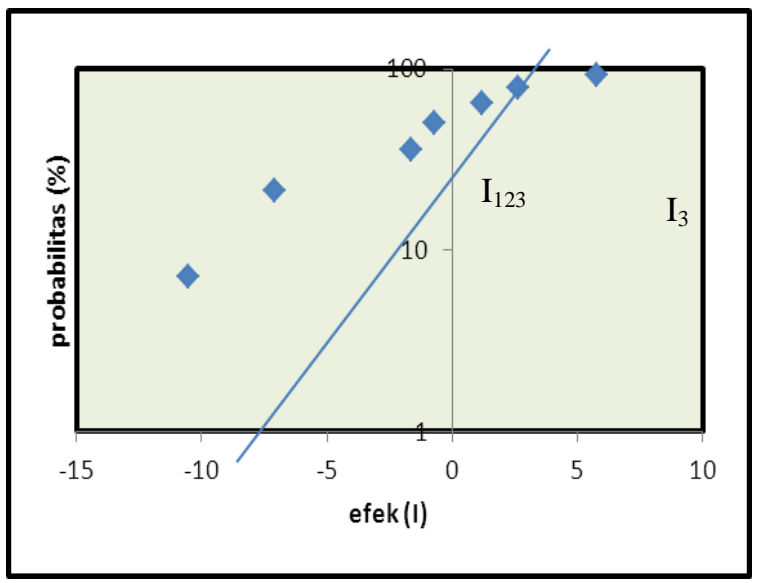

Fig 4. The normal probability

Figure 4 shows probability and the significant effect of variables. The most significant variable is shown by the farthest point of $\mathrm{I}_{123}$. Therefore, the interaction of three variables is the most significant in the production of biodiesel from rubber seed oil using ultrasound. The second most significant affect is type of catalyst while the third is the mesh sizes.

The use of acid catalyst results a higher yield compared to base catalyst. This proved that rubber seed oil contains high FFA (16\%) which needs to be decreased by using esterification reaction prior to trans-esterification using base catalyst.

Oil with FFA more than 2\% should be avoided for trans-esterification processes otherwise this FFA will react with base catalyst through saponification process [6, 17]. This condition leads to decreasing yield of biodiesel production and difficulty in separation. Figure 8 shows gas chromatography analysis result for biodiesel from rubber seed oil. Methyl esters in this sample are: methyl palmitate, methyl palmitonat, methyl stearate, methyl oleat, methyl linoleat, methyl arachidate, methyl linolenat.

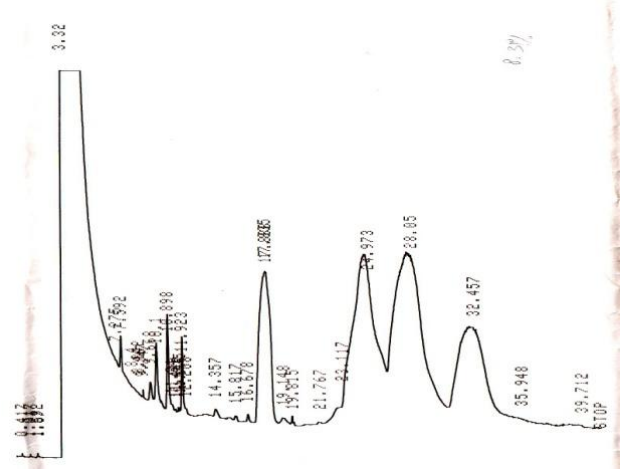

(a)

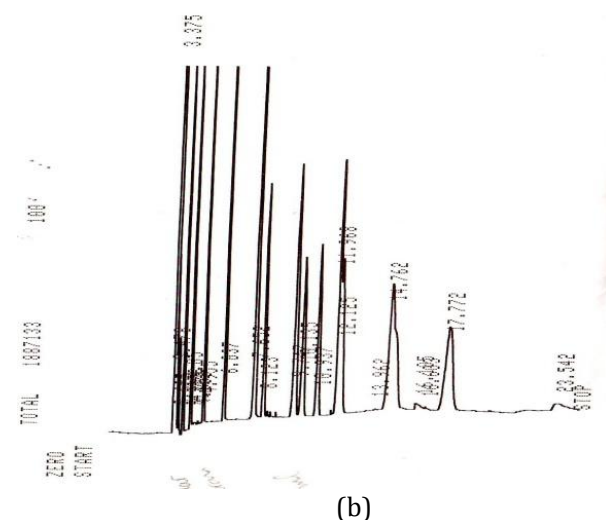

Fig 5. GC analysis of biodiesel (a). Standard ,(b) Biodiesel from experiment

Table 4

Anova analysis

\begin{tabular}{|c|c|c|c|c|c|c|}
\hline & Regressn & Std.Err. & $t(2)$ & p & $-95 \%$ & $+95 . \%$ \\
\hline Mean/Interc. & 43.4894 & 5.02414 & 8.65609 & 0.013085 & 21.8723 & 65.10659 \\
\hline Curvatr. & -19.0488 & 11.23432 & -1.69559 & 0.232051 & -67.3862 & 29.28860 \\
\hline (1)Mesh sizes & -0.6926 & 5.02414 & -0.13786 & 0.902980 & -22.3098 & 20.92453 \\
\hline (3)Type of catalyst & -7.1042 & 5.02414 & -1.41402 & 0.292942 & -28.7214 & 14.51292 \\
\hline 1 by 2 & 2.6451 & 5.02414 & 0.52648 & 0.651113 & -18.9720 & 24.26226 \\
\hline 1 by 3 & -1.6557 & 5.02414 & -0.32954 & 0.773058 & -23.2728 & 19.96147 \\
\hline 2 by 3 & 5.7586 & 5.02414 & 1.14618 & 0.370357 & -15.8586 & 27.37572 \\
\hline
\end{tabular}




\subsection{Reactive-extractive process}

The interaction between two variables is shown by Figure 6:
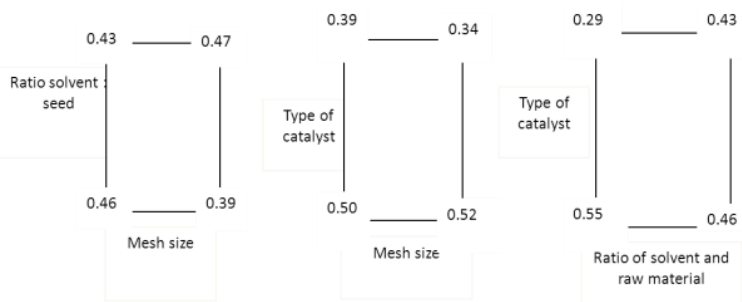

Fig 6. Variable interaction analysis

The figure can be described as interaction of mesh sizes and ratio of solvent: raw materials; at the ratio of solvent and raw material 2:1, the changing of mesh sizes from 1 to $1.16 \mathrm{~mm}$ decrease the yield $7 \%$, while at ratio $3: 1$ the yield only decrease $4 \%$. Interaction of mesh sizes and type of catalyst; for acid catalyst, the increase of mesh size from 1 to $1.6 \mathrm{~mm}$ will decrease the yield about $2 \%$, while for base catalyst; the decrease will be $5 \%$. Interaction of solvent ratio and type of catalyst, for acid catalyst, increasing ratio from $2: 1$ to $3: 1$ will increase the yield by $9 \%$ while for base catalyst will increase the yield by $14 \%$.

\section{Conclusion}

Process of extraction and esterification of rubber seed oil can occur simultaneously to form biodiesel assisted by ultrasound wave. The mathematical model of this process is: $\mathrm{Y}=43,4894-0,6926 \mathrm{X}_{1}+1,1807 \mathrm{X}_{2}-$ $7,1042 X_{3}+2,6451 X_{1} X_{2}-1,6557 X_{1} X_{3}+5,7586 X_{2} X_{3}-$ $10,5145 \mathrm{X}_{1} \mathrm{X}_{2} \mathrm{X}_{3}$. Type of catalyst and interaction of three variables are a significant affect in the formation of biodiesel process.

\section{Acknowledgement}

This research was supported by advanced research grant cluster energy, Faculty of Engineering, Diponegoro University 2010 under assignment number: 281/H7.3.3/IV/2010.

\section{References}

[1] Ibrahim HD, Thaib NM, Wahid LMA (2010) Indonesian Energy Scenario to 2050: Projection of Consumption, Supply Options and Primary Energy Mix Scenarios.

[2] Haeni JH, Green C, Setianto E (2008) Indonesia Energy Assessment. USAID.

[3] Ma F, Hanna MA (1999) Biodiesel Production : A Review. Bioresour Technol. 1-15.

[4] Ikwuagwu OE, Ononogbu IC, Njoku OU, (2000) Production of Biodiesel using Rubber [Hevea brasiliensis] Seed Oil. Ind Crops Prod 12:57-62.

[5] Ramandhas AS, Jayaraj S, Muraleedharan C (2005) Biodiesel Production from High FFA Rubber Seed Oil. Fuel 84: 335-340.

[6] Canakci M, Van Gerpan J (1999) Biodiesel Production via Acid Catalysis. Trans Am Soc Agric Eng 42(5):1203-1210.

[7] Edmondsl, Peter D, Marton, Marton C (1981) Ultrasonic (Methods of Experimental Physics ; v.19). Academic Press, Inc. New York.

[8] Caili F, Haijun T, Quanhong L, Tongyi C, Wenjuan D (2006) Ultrasound-assisted Extraction of Xyloglucan from Apple Pomace. Ultrasonics Sonochemistry 13: 511-516.

[9] Garcia JLL, Castro MDL (2003) Ultrasound: A Powerful for Leaching. Trends in Anal. Chem. 22: 41-47.

[10] Garcia JLL, Castro MDL (2004) Ultrasound-assisted Soxhlet Extraction: An Expeditive Approach for Solid Sample Treatment: Application to The Extraction of Total Fat from Oleaginous Seeds. Journal of Chromatography A 1034: 237-242.

[11] Henwimol S, Pavasant P, Shotiprik A (2006) UltrasoundAssisted Extraction of Anthraquinones from Roots of Morinda Citrifoli. Ultrasonics Sonochemistry 13: 543-548.

[12] Jacques RA, Freitas, LS, Perez VF, Dariva C, Oliveira AP, Oliveira JV, Caramao EB The Use of Ultrasound in The Extraction of Ilex paraguariensis Leaves: A Comparison with Maceration", Ultrasonics Sonochemistry 14: 6-12.

[13] Ji J, Lu X, Cai M, Xu Z (2006) Improvement of Leaching Process of Geniposide with Ultrasound. Ultrasonics Sonochemistry 11, 43-48

[14] Suherman, Widayat, Berkah FTK, Fitria Y, Rochmatika B (2008) Pengaruh Perlakuan Bahan Baku dan Ukuran Bahan Baku dalam Pengambilan Minyak Biji Karet. Semarang. Universitas Diponegoro, hlm. 3.

[15] Mason TJ, Paniwnyk L, Lorimer, JP (1996) The Uses of Ultrasound in Food Technology. Ultrasonics Sonochemistry 3: S253-S260. Sonochemistry Centre, School of Natural and Environmental Studies, Coventry University, Coventry CV1 5FB, UK.

[16] Lazic, Z'ivorad R (2004) Design of Experiments in Chemical Engineering, WILEY-VCH Verlag GmbH \& Co. KGaA,Weinheim. USA.

[17] Freedman BEHP, Mounts TL (1984) Variables Affecting The Yields of Fatty Ester from Trans-esterified Vegetable Oils. JAOCS. 